suggested by an examination of the Admiralty Tide Tables and a consideration of local conditions.

The sea had maintained in the locality a continuous and arrestingly noticeable flat calm for some days previously; such light winds as occurred being offshore. It also happened that the period coincided (a) with low (summer) H.W. neap tides, August 25-281, and (b) with rather warm weather ${ }^{2}$. Thus the absence of renewal of the water extended over an unusually long and warm period and caused the limpets to be exposed to hot weather conditions at midday. It is known that limpets may not be wetted during a few successive neap tides in calm weather ${ }^{3}$, but the exposure during a set of neap tides following the normal midday exposure at low water of spring tides would impose a severe strain upon the animals.

The death of the limpets on the rim of the pools therefore followed an unusual exposure to sun and air, while those succumbing in the pools had doubtless been subject to large and complicated variations in the little-known co-existing physical and chemical conditions. At the same time limpets accustomed to exposure higher in the foreshore survived, though in a weak condition. These facts confirm the critical nature of the environment round about the level of H.W. neaps ${ }^{5}$. Limiting natural environmental conditions-unfortunately not closely definable--in temperature, humidity, certain chemical and other physical factors were therefore either approached or surpassed in this locality for $P$. vulgata in August 1932.

J. H. Orton.

Department of Zoology,

University of Liverpool. April 6.

1 Admiralty Tide Tables 1932.

${ }^{2}$ Daily Weather Report, British Section, Meteorological office, London.

J. H. Orton, J. of Mar. Biol. Assoc., 16, 279; 1929.

4 J. R. Bruce, Proc. and Trans. Liv. Biol. Snc., p. 19; 1931

5. Colman, J. Mar. Biol. Assoc., 18, 467; 1933.

\section{Measurement of Light for Biological Purposes}

THE measurement of light intensity has always presented certain difficulties to biologists, especially when it was necessary for the measurements to be made under field conditions. The available methods were either slow, or measured only limited spectral ranges, or else involved the use of cumbrous apparatus of limited portability. We have lately used, however, a form of apparatus which seems to be free from these disadvantages. We are so impressed with the usefulness and simplicity of this apparatus that we wish to bring it to the notice of readers of NATURE and particularly to that of biologists.

The essential part of the apparatus is a Bernheim photo-voltaic cell. The current produced by exposing this cell to light is measured by the deflection of a Unipivot galvanometer, which is sufficiently robust to be read easily in a small boat and has already travelled many hundreds of miles in a motor-car over bad roads. A manganin resistance of 1,000 ohms is put into the circuit for readings in full daylight. There is no lag in the readings and there is no dark current. Moreover, there is no reversal of the current at certain spectral ranges, as may be the case in some rectifier photo-cells.

Using this cell enclosed in a watertight container we obtained the following measurements of light penetration in Windermere. For comparison with the figures so obtained are given those measured with a recent form of potassium-on-copper vacuum cell. In using the latter, it is necessary to amplify the primary photoelectric current about two hundred times in order to obtain readings comparable with those of the Bernheim cell. The thermionic potentiometer devised to accomplish the amplification and measurement is naturally somewhat bulky and less readily portable.

$$
\begin{aligned}
& \text { Light intensity at different depths in Windermere. } \\
& \begin{array}{lllllllll}
\text { Depth in m. } & 1 & 2 & \text { February } 8, \underset{3}{1} & 1933 . & 7 & 9 & 11 & 13
\end{array} \\
& \begin{array}{lllllllll}
\text { Bernheim cell } & 38.0 & 19.9 & 11.1 & 3.84 & 1.33 & 0.45 & 0.15 & 0.052
\end{array} \\
& \text { acuum cell } \\
& \begin{array}{lrrrrrr}
\text { amplified } & 36.3 & 15.9 & 7.41 & 1.82 & 0.43 & 0.11
\end{array} \\
& \text { Values as percentages of full daylight. }
\end{aligned}
$$

The greater utility of the Bernheim cell for this type of work is due not only to its greater sensitivity but also to the fact that it is sensitive over the whole range of the visible spectrum. The cell we have employed for outdoor work has the following spectral sensitivity, given as galvanometer deflection per 1,000 ergs per cm. ${ }^{2}$ per sec. (for the facilities necessary to make these determinations we are indebted to Prof. R. Whiddington) :

Wave-length in A. 350042005000570062007000 $\begin{array}{lllllll}\text { Sensitivity } & 1 \cdot 4 & 3 \cdot 0 & 5 \cdot 6 & 6 \cdot 7 & 4 \cdot 8 & 1 \cdot 1\end{array}$

The vacuum cell used in the above mentioned measurements has a maximum sensitivity in the region $4000-4900 \mathrm{~A}$. and only slight sensitivity in the red.

W. H. Pearsall.

P. UlliyotT.

Fresh Water Biological Laboratory, Wray Castle, Ambleside.

\section{Preservation of Fossil Bones}

UNDER the above heading in NaTURE of March 11, p. 366, Mr. Ludovic McL. Mann states that the mammalian bones in the Kelvingrove Museum, Glasgow, "were all found ... in the laminated gravels of the old raised terrace of the Kelvin river, some eight miles east of Glasgow, at about $170 \mathrm{ft}$. O.D."

Readers will probably interpret "raised terrace" as they are accustomed to interpret raised beach, that is, as a terrace originally formed at a lower level and owing its present position to relative eleva. tion of the land. Certainly they will think that the gravel deposit in which the bones were found is a higher terrace of the River Kelvin, in the same way as the implementiferous terraces of southern England are higher terraces of the rivers occupying the valleys.

Recently, I have been studying the Kelvin valley terraces in an attempt to understand the glacial history of the Glasgow district. I think, with other geologists, that there is no connexion between the $170-\mathrm{ft}$. terrace of current-bedded sands and gravels and the present River Kelvin, other than that they occur in the same valley, referred to above as the Kelvin valley.

The late Prof. Gregory ${ }^{1}$, on more than one occasion, gave a Mousterian age to the gravels of these terraces, but it is now clear that they must be very much more recent than the Early Magdalenian.

\section{University of Glasgow.} W. J. McCalimen. April 1.

1 cf. Gregory, J. W., and Currie, E. D., "The Vertebrate Fossils from the Glacial and Post-Glacial Beds of Scotland in the Hunterian Museum, University of Glasgow, and their Evidence on the Classification of the Scottish Glacial Deposits", Monographs of the Geologica Department of the Hunterian Museum, Glasgow University, 1928, p. 20. 